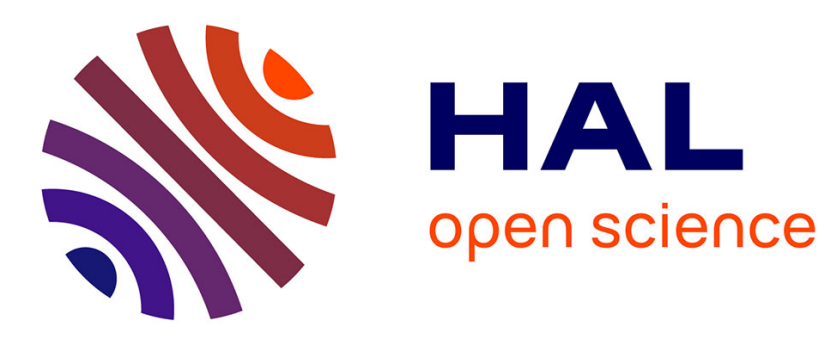

\title{
Hybrid control of a three-cell converter associated to an inductive load
}

Mohamed Trabelsi, Jean-Marie Rétif, Xuefang Lin-Shi, Xavier Brun, Florent Morel, Pascal Bevilacqua

\section{- To cite this version:}

Mohamed Trabelsi, Jean-Marie Rétif, Xuefang Lin-Shi, Xavier Brun, Florent Morel, et al.. Hybrid control of a three-cell converter associated to an inductive load. IEEE PESC, Jun 2008, Rhodes, Greece. pp.3519-3525, 10.1109/PESC.2008.4592500 . hal-00374698

\section{HAL Id: hal-00374698 https://hal.science/hal-00374698}

Submitted on 3 Jun 2009

HAL is a multi-disciplinary open access archive for the deposit and dissemination of scientific research documents, whether they are published or not. The documents may come from teaching and research institutions in France or abroad, or from public or private research centers.
L'archive ouverte pluridisciplinaire HAL, est destinée au dépôt et à la diffusion de documents scientifiques de niveau recherche, publiés ou non, émanant des établissements d'enseignement et de recherche français ou étrangers, des laboratoires publics ou privés. 


\title{
Hybrid Control of a Three-Cell Converter Associated to an Inductive Load
}

\author{
M. Trabelsi, J.M. Retif, X. Lin-Shi, X. Brun, F. Morel, P. Bevilacqua \\ INSA-Lyon, Laboratory AMPERE CNRS UMR 5005, Villeurbanne, France \\ mohamed.trabelsi@insa-lyon.fr
}

\begin{abstract}
This paper presents a control scheme for a multilevel multi-cell converter. For this type of converters, load current and capacitor voltages must be jointly controlled. Moreover the real-time constraint is important. This constraint leads us to propose a control based on a simplified state-space model. The model allows predicting the state vector evolution for every converter configuration. The control algorithm directly determines the converter switching state which minimizes a simple cost function. A normalization of the state variables is proposed for the cost function calculation in order to ensure a trade-off between the tracking of the load current and the tracking of the capacitor voltages. The proposed control scheme is detailled and compared with a classical control scheme with simulations. Finally, experimental results are presented to show the effectiveness of the proposed method.
\end{abstract}

Keywords - Dynamic Hybrid Systems, Multi-cell converter, Hybrid control, Digital Signal Processing.

\section{INTRODUCTION}

A large number of industrial applications are composed of a continuous process controlled by an energy modulator which has a finite number of configurations. These systems constitute a class of Hybrid Dynamic Systems (HDS). In the field of power electronics, static converters associated with a load is an example of this class of HDS.

During this last decade, multi-cell converters have grown from an attractive concept to industrial applications, especially for use in high-power applications [1] [2]. Indeed, the output waveforms of this type of topologies are improved compared to the classical twolevel converter technologies with the same switching frequency. These structures also allow reducing filtering elements. Fig. 1 shows a three-cell converter feeding a passive load formed by an inductor (L) and a resistor (R). The control objective is to control the load current (I) as well as the capacitor voltages $\left(E_{1}\right.$ and $\left.E_{2}\right)$. Generally a continuous control approach is used. Later, a modulation strategy is applied to translate the continuous control into switching orders [3]. For example, a nonlinear control by input-output linearization is proposed in [4]. Recently, a passivity based control using an averaged model [5], a stabilizing method using a Lyapunov function and a predictive control approach with optimization procedures [6] have been compared in [7].

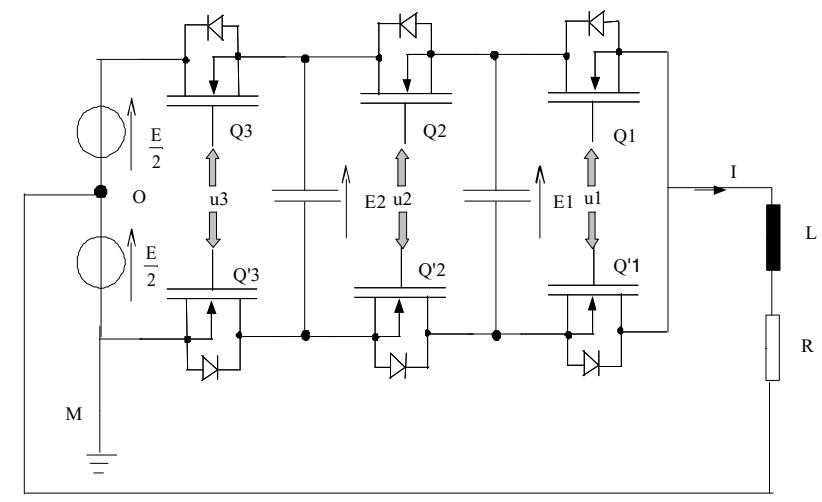

Fig. 1. The three-cell converter

In this paper, a direct control is proposed where the control variables are directly the converter switching states, so any modulation strategy is necessary. The control scheme takes into account the hybrid nature of the system. In this context, the hybrid control term is used in the following sections.

\section{HYBRID CONTROL APPROACH}

In the hybrid control context, the actuator and the continuous process are not separated for the modelling. So the state model includes continuous and discrete variables. Hybrid control directly chooses discrete state of the actuator in order to track the reference values for the continuous process state vector. Fig. 2 shows the synoptic of the hybrid control.

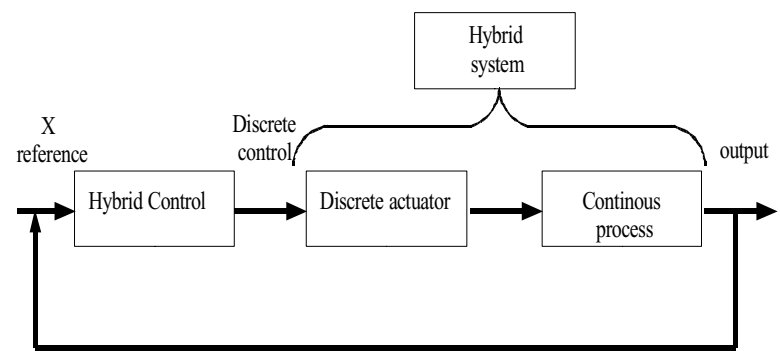

Fig. 2. Hybrid control synoptic 
The hybrid control approach includes four fundamental steps. The first one consists in modelling the hybrid system by taking in consideration both the discrete and the continuous variables. The obtained model may be nonlinear. In the case where the real-time constraint is important, a second step consists on finding a simplified model valid for a computation occurrence which will be computed for each possible system configuration at each calculation period. In the third step, hybrid control uses a choice strategy to select a configuration which minimizes a cost function. Finally, the selected configuration is applied for the next sampling period.

In this paper, these steps are detailed for the three-cell converter. Simulated results will be compared between a classical PWM control and the hybrid proposed control. Finally, experimental results obtained with the proposed control approach will be exposed.

\section{THREE-CELL DC-DC CONVERTER MODEL}

In the following section, a simple algebraic method will be detailed in order to find an explicit standard model including all the converter configurations.

\section{A. Hybrid Model}

For the proposed hybrid control, an instantaneous model of the three-cell dc-dc converter involving continuous elements (capacitors, inductor and resistor) as well as discrete elements (switching states) is used. The switching state associated with each commutation cells $\left(Q_{j}, Q_{j}^{\prime}\right)$ is noted as $u_{j} \in\{0,1\}(j=1,2,3)$. When $u_{j}=1$, the upper switch of the cell $\mathrm{j}$ is "on" and the lower switch is "off" whereas it will be "off" whenever $u_{j}=0$ and the lower switch is "on". From electrical equations, it can be written:

$$
\begin{gathered}
\mathrm{C}_{1} \frac{\mathrm{dE}_{1}}{\mathrm{dt}}=\mathrm{I}\left(\mathrm{u}_{2}-\mathrm{u}_{1}\right) ; \mathrm{C}_{2} \frac{\mathrm{dE}_{2}}{\mathrm{dt}}=\mathrm{I}\left(\mathrm{u}_{3}-\mathrm{u}_{2}\right) \\
\mathrm{V}_{\mathrm{ao}}=\mathrm{L} \frac{\mathrm{dI}}{\mathrm{dt}}+\mathrm{R} . \mathrm{I}
\end{gathered}
$$

By noting $\mathrm{V}_{\mathrm{swj}}$ the voltage on the transistor $\mathrm{Q}_{\mathrm{j}}{ }_{\mathrm{j}}$, it can be written:

$$
\begin{aligned}
& \mathrm{V}_{\mathrm{sw} 3}=\mathrm{u}_{3}\left(\mathrm{E}-\mathrm{E}_{2}\right) ; \quad \mathrm{V}_{\mathrm{sw} 2}=\mathrm{u}_{2}\left(\mathrm{E}_{2}-\mathrm{E}_{1}\right) \\
& \mathrm{V}_{\mathrm{sw} 1}=\mathrm{u}_{1} \cdot \mathrm{E}_{1} \\
& \mathrm{~V}_{\mathrm{ao}}+\frac{\mathrm{E}}{2}=\mathrm{V}_{\mathrm{sw} 1}+\mathrm{V}_{\mathrm{sw} 2}+\mathrm{V}_{\mathrm{sw} 3}
\end{aligned}
$$

By choosing the two flying capacitor voltages $E_{1}(t)$, $E_{2}(t)$ and the load current $I(t)$ as three state variables noted $\underline{X}(t)=\left[\begin{array}{lll}E_{1}(t) & E_{2}(t) & I(t)\end{array}\right]^{T}$, switching states of the commutation cells $\underline{U}(t)=\left[\begin{array}{lll}u_{3} & u_{2} & u_{1}\end{array}\right]^{T}$ as the control vector, the state equation, obtained from (1) and (2) can be written as follow:

$$
\underline{\dot{X}}(\mathrm{t})=\underbrace{\left(\begin{array}{ccc}
0 & 0 & \frac{\mathrm{u}_{2}-\mathrm{u}_{1}}{\mathrm{C} 1} \\
0 & 0 & \frac{\mathrm{u}_{3}-\mathrm{u}_{2}}{\mathrm{C} 2} \\
\frac{\mathrm{u}_{1}-\mathrm{u}_{2}}{\mathrm{~L}} & \frac{\mathrm{u}_{2}-\mathrm{u}_{3}}{\mathrm{~L}} & -\frac{\mathrm{R}}{\mathrm{L}}
\end{array}\right)}_{\mathrm{A}(\mathrm{u})} \cdot \underline{X}(\mathrm{t})+\underbrace{\left(\begin{array}{c}
0 \\
0 \\
\frac{1}{\mathrm{~L}} \cdot \mathrm{u}_{3}-\frac{1}{2 L}
\end{array}\right)}_{B(\mathrm{u})} . \mathrm{E}
$$

For the considered converter, there are two switching states for each leg, so that eight different configurations are noted, from $\mathrm{U}_{1}$ to $\mathrm{U}_{8} \quad\left(\underline{\mathrm{U}}_{\mathrm{i}}(\mathrm{t}), \mathrm{i}=1, \ldots, 8\right)$ with $\mathrm{U}_{\mathrm{i}}=\left[\begin{array}{lll}\mathrm{u}_{3} & \mathrm{u}_{2} & \mathrm{u}_{1}\end{array}\right]$. The hybrid model (3) can be expressed by:

$$
\dot{\mathrm{X}}_{\mathrm{i}}(\mathrm{t})=\mathrm{A}_{\mathrm{i}} \cdot \underline{\mathrm{X}}(\mathrm{t})+\mathrm{B}_{\mathrm{i}}
$$

For a given configuration $U_{i}, A_{i}$ and $B_{i}$ are constant matrix. So a corresponding discrete-time model for a sampling period $\mathrm{T}_{\mathrm{e}}$ can be calculated:

$$
\underline{\mathrm{X}}_{\mathrm{i}}(\mathrm{k}+1)=\phi_{\mathrm{i}}\left(\mathrm{T}_{\mathrm{e}}\right) \cdot \underline{\mathrm{X}}(\mathrm{k})+\Psi_{\mathrm{i}}\left(\mathrm{T}_{\mathrm{e}}\right) \cdot \mathrm{B}_{\mathrm{i}}
$$

with $\phi_{\mathrm{i}}\left(\mathrm{T}_{\mathrm{e}}\right)=\mathrm{e}^{\mathrm{A}_{\mathrm{i}} \mathrm{Te}}$ and $\Psi_{\mathrm{i}}\left(\mathrm{T}_{\mathrm{e}}\right)=\int_{0}^{\mathrm{T}_{\mathrm{e}}} \phi_{\mathrm{i}}(\theta) \cdot \mathrm{d} \theta$

\section{B. Simplified Model}

As the real-time constraint is important for the considered system, a simplified model is mandatory.

If the sample time is sufficiently small, the state trajectories in the state space can be considered as rectilinear. With this hypothesis, the 8 states at time $(\mathrm{k}+1)$ in the state space can be approximated by:

$$
\underline{\tilde{X}}_{i}(k+1)=\underline{X}(k)+\underline{X}_{i}(t) \cdot T_{e}
$$

From a measured state $\underline{X}(\mathrm{k})$, by using (6), the 8 possible directions in the state space after $T_{e}$ can be determined. Fig. 3 shows an example of these directions.

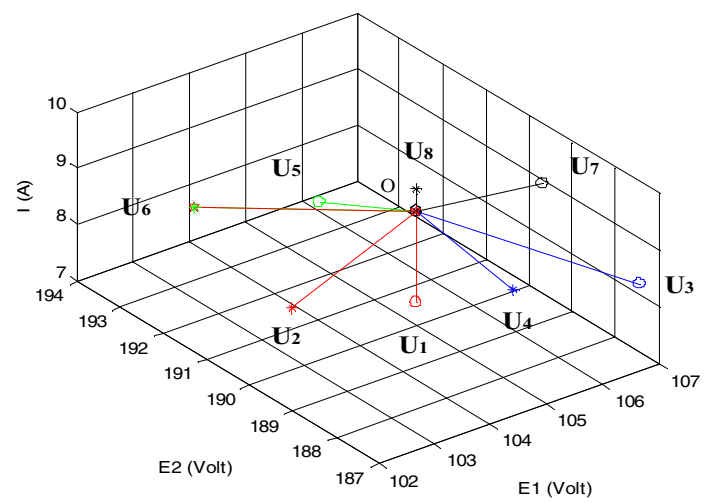

Fig. 3. Example of possible state-vector directions in the state space at a given operating point 
For the configurations $\mathrm{U}_{1}$ and $\mathrm{U}_{8}$, the capacitor voltages are constant and the load current varies.

For the configurations $\mathrm{U}_{2}$ to $\mathrm{U}_{7}$, the load current traverses one or two capacitors and the voltage variations are proportional to the current.

\section{Validity Domain of the Simplified Model}

In order to verify the validity of the simplified model, simulation studies have been made by comparing the discrete-time model (5) and the simplified model (6) with:

$$
\mathrm{E}=300 \mathrm{~V}, \mathrm{C}_{1}=\mathrm{C}_{2}=33 \mu \mathrm{F}, \mathrm{R}=33 \Omega, \mathrm{L}=50 \mathrm{mH}, \mathrm{T}_{\mathrm{e}}=100 \mu \mathrm{s}
$$

Fig. 4 shows the simulation results for the configuration $\mathrm{U}_{2}$ when the load current $\mathrm{I}=0.5 \mathrm{~A}$. It can be seen that in the plane $\left(\mathrm{E}_{1}, \mathrm{E}_{2}\right)$, the trajectory from $\mathrm{E}_{1}(\mathrm{k})=100 \mathrm{~V}$, $\mathrm{E}_{2}(\mathrm{k})=200 \mathrm{~V}$ after $\mathrm{T}_{\mathrm{e}}$ will be ever rectilinear but the final point calculated with the discrete-time model is different to the final point calculated with the simplified model. This difference changes with the load current.

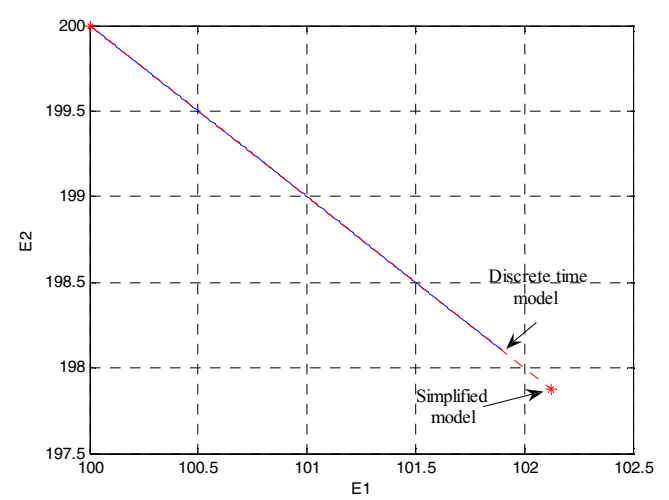

Fig. 4. Difference between discrete final point and approximate final point

We note $\operatorname{ErrE}_{1}$, ErrE $_{2}$ and ErrI the voltage and current errors between the simplified model and the discrete-time model.

It can be seen from Fig. 5 and Fig. 6 that these errors are proportional to the load current.

We note that the max error on $E_{2}$ is similar to on $E_{1}$ for different configurations. This can be explained by the fact that the two capacitors are identical.

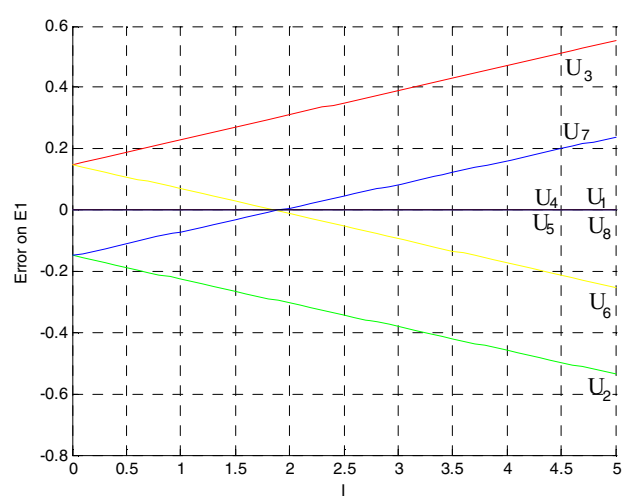

Fig. 5. Error on $E_{1}(\mathrm{~V})$ versus I (A)

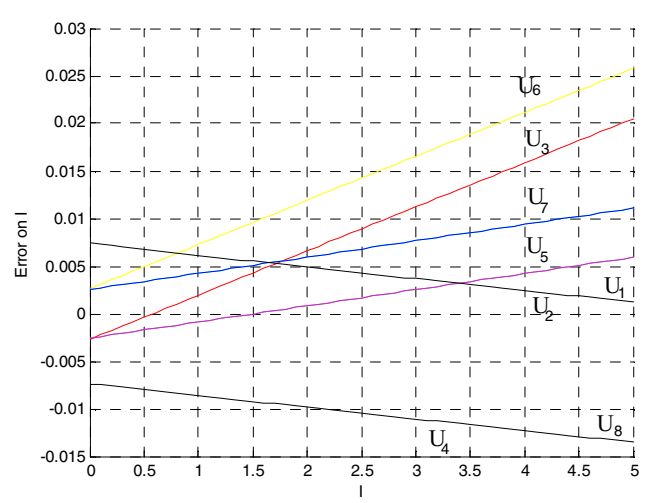

Fig. 6. Error on I (A) versus I (A)

As shown by Fig. 5 and Fig. 6, the maximum errors due to the simplified model are too small, $0.6 \%$ for $\mathrm{E}_{1}$ and $0.3 \%$ for $\mathrm{E}_{2}$ and $25 \mathrm{~mA}$ for the load current.

This phenomenon can be explained by algebraic way from the expressions of the estimated states as given in the following for the voltage $E_{1}$. The expressions of the voltage value $E_{1}$ after a sampling period determined by the model (5) and (6) are respectively:

$$
\begin{gathered}
\mathrm{E}_{1 \mathrm{i}}(\mathrm{k}+1)=\phi_{\mathrm{l}}(\mathrm{Te}) \cdot \mathrm{E}_{1}(\mathrm{k})+\Psi_{\mathrm{i}}(\mathrm{Te}) \cdot \mathrm{B}_{\mathrm{i}} \\
\tilde{\mathrm{E}}_{1 \mathrm{i}}(\mathrm{k}+1)=\mathrm{E}_{1}(\mathrm{k})+\dot{\mathrm{E}_{1 \mathrm{i}}} \cdot \mathrm{Te}
\end{gathered}
$$

Taking, for example, as configuration $U_{3}=\left[\begin{array}{lll}0 & 1 & 0\end{array}\right],(7)$ and (8) become:

$$
\begin{gathered}
\mathrm{E}_{13}(\mathrm{k}+1)=\left[\beta \cdot\left(\mathrm{E}_{1}(\mathrm{k}), \mathrm{E}_{2}(\mathrm{k})\right)+\delta \cdot \mathrm{I}(\mathrm{k})\right]+\Psi(\mathrm{Te}) \cdot \mathrm{B}_{3} \\
\tilde{\mathrm{E}}_{13}(\mathrm{k}+1)=\mathrm{E}_{1}(\mathrm{k})+\frac{\mathrm{Te}}{\mathrm{C}_{1}} \cdot \mathrm{I}(\mathrm{k})
\end{gathered}
$$

where $\beta$ and $\delta$ are constant which depend on Taylor series expansion of $\phi_{3}\left(T_{e}\right)=e^{A_{3} T e}$

For the simulation, this expansion is developed in the fifth order. So the constant $\delta$ will be different to the constant $\frac{\mathrm{Te}}{\mathrm{C}_{1}}$. Consequently, in the error expression given by (11):

$$
\begin{aligned}
\operatorname{ErrE}_{13} & =\tilde{\mathrm{E}}_{13}(\mathrm{k}+1)-\mathrm{E}_{13}(\mathrm{k}+1) \\
= & \underbrace{\left(\mathrm{E}_{1}(\mathrm{k})-\beta\left(\mathrm{E}_{1}(\mathrm{k}), \mathrm{E}_{2}(\mathrm{k})\right)-\Psi(\mathrm{Te}) \cdot \mathrm{B}_{3}\right)}_{\text {cons tan } \mathrm{t}}+\underbrace{\lambda}_{\neq 0} \cdot \mathrm{I}(\mathrm{k})
\end{aligned}
$$

the coefficient $\lambda$ of the load state $\mathrm{I}(\mathrm{k})$ will not be null and the error is proportional to the load current. This phenomenon is true for all configurations $U_{i}$. The same explanation can be given for the voltage $E_{2}$ and the load current I.

Due to the small errors shown in this section, the simplified model is validated for the considered application.

\section{CONTROL STRATEGY}

The proposed control proceeds as follows during each sampling period: 
- Measure capacitor voltages $\mathrm{E}_{1}(\mathrm{k}), \mathrm{E}_{2}(\mathrm{k})$ and load current I(k).

- Predict the state vector $\underline{\tilde{X}}_{\mathrm{i}}(\mathrm{k}+1)=\left[\begin{array}{lll}\tilde{\mathrm{E}}_{1 \mathrm{i}}(\mathrm{k}+1) & \tilde{\mathrm{E}}_{2 \mathrm{i}}(\mathrm{k}+1) & \tilde{\mathrm{I}}_{\mathrm{i}}(\mathrm{k}+1)\end{array}\right]^{\mathrm{T}}$ for the 8 possible control vectors $\underline{U}_{\mathrm{i}}(\mathrm{t})$ by using $(6)$.

- For a desired reference state $\underline{X}_{c}=\left[\begin{array}{lll}E_{1 c} & E_{2 c} & I_{c}\end{array}\right]^{T}$, the control selects the configuration which gives the smallest distance between $\underline{\tilde{X}}_{\mathrm{i}}(\mathrm{k}+1)$ and $\underline{X}_{c}=\left[\begin{array}{lll}E_{1 c} & E_{2 c} & I_{c}\end{array}\right]^{T}$.

The desired reference state is a point in the state space with the coordinates $E_{1 c}, E_{2 c}$ and $I_{c}$. The choice of the capacitor voltages references influences on the values of the output voltage and the quality of the tracking.

\section{A. Voltage Reference Choice}

Generally, $\mathrm{E}_{1 \mathrm{c}}=\frac{\mathrm{E}}{3}, \mathrm{E}_{2 \mathrm{c}}=\frac{2 \mathrm{E}}{3}$ are chosen in order to share out the voltages on the cells. This section will prove that these voltage references allow the maximum freedom degrees in the state space. The freedom degree is defined as the possibility of increase or decrease of a state variable.

Considering the state variations with a positive value of the load current, the projection in the plane $\left(E_{1}, E_{2}\right)$ of the vector evolutions relative to the 8 converter configurations is shown by Fig. 7.

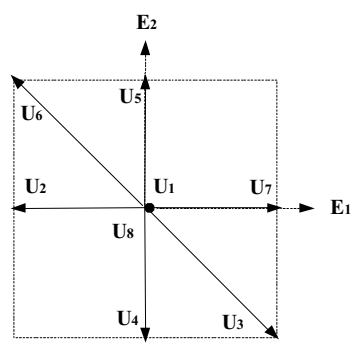

Fig. 7. State vectors projections in the plane $E_{1} E_{2}$ for $I>0$

From (3), it can be determined the derivative of the load current for each configuration (Table I).

TABLE I.

CURRENT Derivative

\begin{tabular}{|c|c|}
\hline Configuration & Current Derivative \\
\hline $\mathrm{U}_{1}$ & $\frac{-\mathrm{E}-2 . \mathrm{R} . \mathrm{I}}{2 . \mathrm{L}}$ \\
\hline $\mathrm{U}_{2}$ & $\frac{2 . E_{1}-E-2 . R . I}{2 L}$ \\
\hline $\mathrm{U}_{3}$ & $\frac{-\mathrm{E}-2 . \mathrm{E}_{1}+2 . \mathrm{E}_{2}-2 . \mathrm{R} . \mathrm{I}}{2 \mathrm{~L}}$ \\
\hline $\mathrm{U}_{4}$ & $\frac{-\mathrm{E}+2 . \mathrm{E}_{2}-2 . \mathrm{R} . \mathrm{I}}{2 \mathrm{~L}}$ \\
\hline $\mathrm{U}_{5}$ & $\frac{-\mathrm{E}-2 . \mathrm{E}_{2}-2 . \mathrm{R} . \mathrm{I}}{2 \mathrm{~L}}$ \\
\hline $\mathrm{U}_{6}$ & $\frac{\mathrm{E}+2 . \mathrm{E}_{1}-2 . \mathrm{E}_{2}-2 . \mathrm{R} . \mathrm{I}}{2 \mathrm{~L}}$ \\
\hline $\mathrm{U}_{7}$ & $\frac{\mathrm{E}-2 . \mathrm{E}_{1}-2 . \mathrm{R} . \mathrm{I}}{2 \mathrm{~L}}$ \\
\hline $\mathrm{U}_{8}$ & $\frac{\mathrm{E}-2 . \mathrm{R} . \mathrm{I}}{2 . \mathrm{L}}$ \\
\hline
\end{tabular}

On the Fig. 8, the straight lines in the lowers triangles refer to the null variation of the load current (the configurations $\mathrm{U}_{1}$ and $\mathrm{U}_{8}$ are not presented because the capacitor voltages are constant). The $(+)$ area refers to the positive variation of the current load and the $(-)$ area refers to the negative variation.
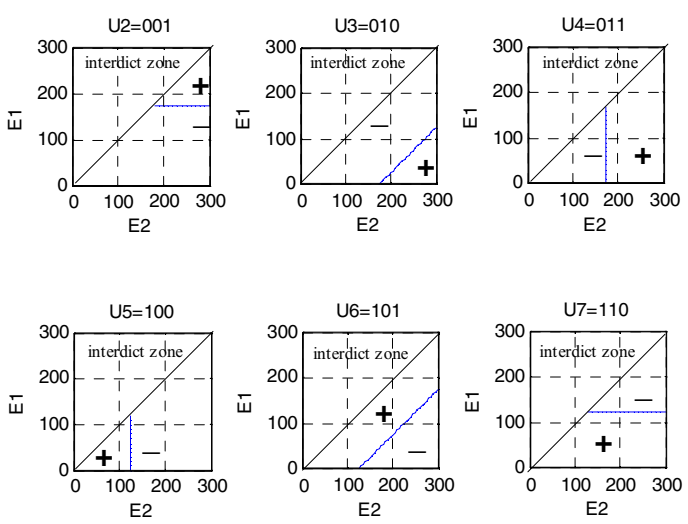

Fig. 8. Iso-increase of the load current on the voltages plane

The concatenation of these areas in the same plane $\left(E_{2}\right.$, $\mathrm{E}_{1}$ ) allows parting the plane in ten areas as presented in Fig. 9.

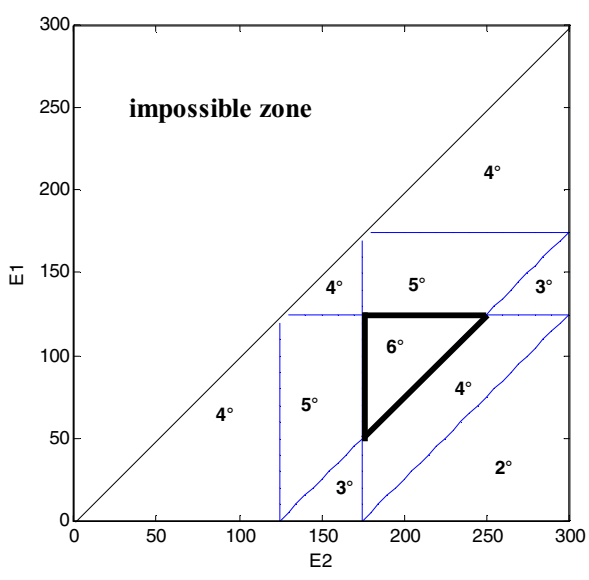

Fig. 9. Reference areas on the plane $\left(E_{2}, E_{1}\right)$

Each area refers to voltages references and is marked by the number of freedom degrees available to reach this reference. The best choice is the voltage references which correspond to maximum freedom degree area.

For $\mathrm{E}=300 \mathrm{~V}$, the choice of the classic reference $\mathrm{E}_{1} \mathrm{c}=\frac{\mathrm{E}}{3}=100 \mathrm{~V}, \mathrm{E}_{2} \mathrm{c}=\frac{2 \mathrm{E}}{3}=200 \mathrm{~V}$ leads to 6 freedom degrees which is maximum.

\section{B. Choice Strategy}

At each sampling period, the control algorithm calculates the distance between the reference point and the reached point of each configuration. The configuration which corresponds to the minimal distance is selected. This choice strategy does not allow to reach suitably the reference. On the one hand, state vector components are not homogeneous (Ampere and Volt). On the other hand, the weight of the components are very different for the 
considered application (hundreds Volt for voltages and a few Ampere for current).

Due to these facts, the state variables are normalized. The normalization influences the configuration selection. By choosing:

$$
\left\{\begin{array}{l}
\Delta \mathrm{E}_{1}=\left|\max \left(\tilde{\mathrm{E}}_{1 \mathrm{i}}(\mathrm{k}+1)\right)-\min \left(\tilde{\mathrm{E}}_{1 \mathrm{i}}(\mathrm{k}+1)\right)\right| \\
\Delta \mathrm{E}_{2}=\left|\max \left(\tilde{\mathrm{E}}_{2 \mathrm{i}}(\mathrm{k}+1)\right)-\min \left(\tilde{\mathrm{E}}_{2 \mathrm{i}}(\mathrm{k}+1)\right)\right| \\
\Delta \mathrm{I}=\left|\max \left(\tilde{\mathrm{I}}_{\mathrm{i}}(\mathrm{k}+1)\right)-\min \left(\tilde{\mathrm{I}}_{\mathrm{i}}(\mathrm{k}+1)\right)\right|
\end{array}\right.
$$

the distance between $\underline{\tilde{X}}_{\mathrm{i}}(\mathrm{k}+1)$ and $\underline{X}_{c}=\left[\begin{array}{lll}E_{1 c} & E_{2 c} & I_{c}\end{array}\right]^{T}$ after normalization is calculated by:

$$
\operatorname{dist}_{\mathrm{i}}=\sqrt{\left(\frac{\mathrm{E}_{1 \mathrm{c}}-\tilde{\mathrm{E}}_{1 \mathrm{i}}}{\Delta \mathrm{E}_{1}}\right)^{2}+\left(\frac{\mathrm{E}_{2 \mathrm{c}}-\tilde{\mathrm{E}}_{2 \mathrm{i}}}{\Delta \mathrm{E}_{2}}\right)^{2}+\left(\frac{\mathrm{I}_{\mathrm{c}}-\tilde{\mathrm{I}}_{\mathrm{i}}}{\mu . \Delta \mathrm{I}}\right)^{2}}
$$

$\boldsymbol{\mu}$ is a weighting factor which allows a trade-off between the current tracking and the voltage tracking. Indeed, a good tracking of the capacitor voltages leads to oscillations on the load current. For better current tracking, voltage tracking performance must be reduced. The factor $\mu$ is determined experimentally and is kept constant during the running of the algorithm. When $\mu$ is small, the priority is given to the current tracking. When $\mu$ is large, it favours the voltages tracking.

\section{COMPARISON WITH PWM CONTROL}

In order to show the advantages of the proposed control, simulation study has been performed to make a comparison with the classical PWM control.

The PWM control applied to the three-cell converter consists on comparing a reference signal chosen sinusoidal with three triangle waveforms which have the same period $\mathrm{T}_{\text {mod }}$ but phase-shifted to $\mathrm{T}_{\text {mod }} / 3$ and $2 \mathrm{~T}_{\text {mod }} / 3$. The reference signal is given by a current PI controller.

The simulation of the hybrid control and the PWM control are made on the same conditions than the experiment study presented in the previous section: $\mathrm{C}_{1}=\mathrm{C}_{2}=33 \mu \mathrm{F}, \mathrm{R}=33 \Omega, \mathrm{L}=50 \mathrm{mH}, \mathrm{E}=120 \mathrm{~V}$. The voltages references are chosen as $\mathrm{E}_{1} \mathrm{c}=\frac{\mathrm{E}}{3}, \mathrm{E}_{2} \mathrm{c}=\frac{2 \mathrm{E}}{3}$ while a sinusoidal current reference is imposed. For the PWM control, $\mathrm{T}_{\bmod }=1 \mathrm{~ms}$ and the computation period is $10 \mu \mathrm{s}$.

Fig. 10 and Fig. 11 show the tracking of the load current with the two controls. The simulation test of the hybrid control is made with a small value of the weighting factor $\mu$.

Fig. 12, Fig. 13 and Fig. 14 show the waveforms of the capacitor voltages and the load voltage.

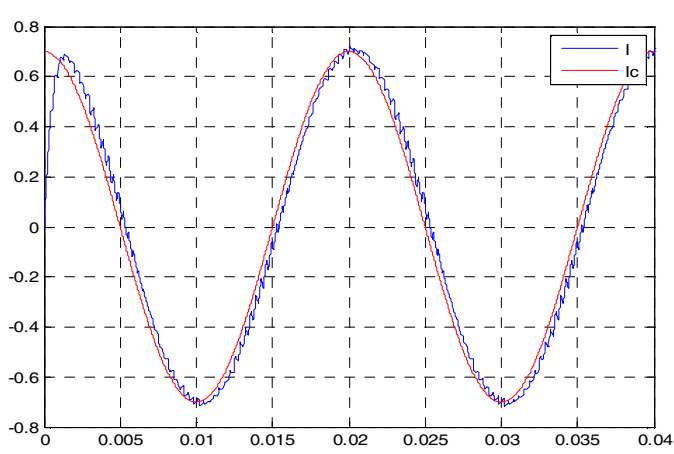

Fig. 10. Load current (A) with the PWM control versus time (s)

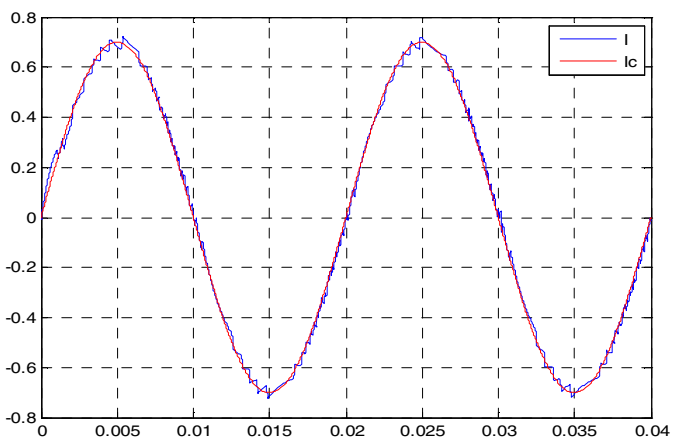

Fig. 11. Load current (A) with the Hybrid control versus time (s)
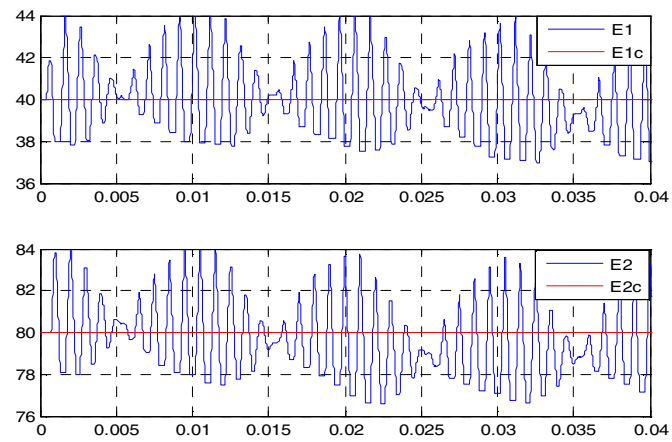

Fig. 12. Capacitors voltages (V) with the PWM control versus time (s)
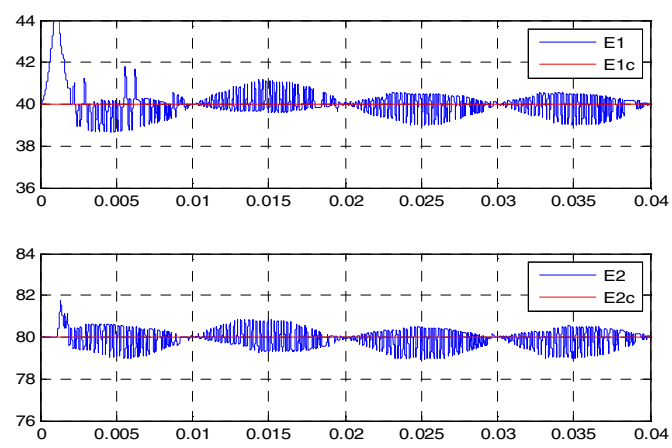

Fig. 13. Capacitors voltages (V) with the Hybrid control versus time (s) 


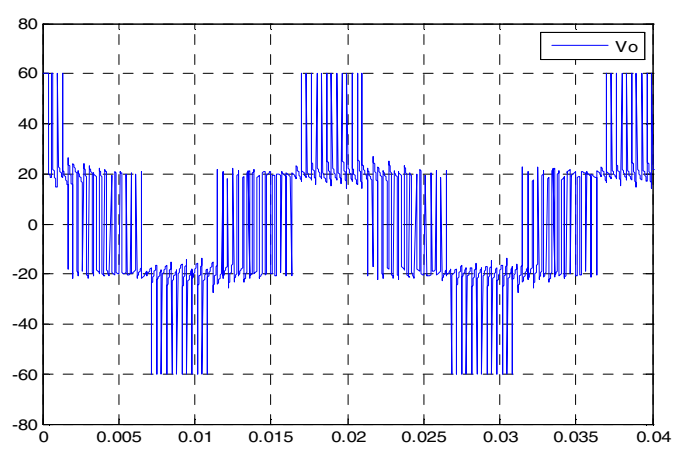

Fig. 14. Load voltage (V) versus time (s)

With the PWM control, a phase shift between the reference and the obtained load current can be noted.

It can be noted also that the voltage errors in the hybrid case are about $\pm 1 \mathrm{~V}$ while the PWM control has about \pm $4 \mathrm{~V}$ voltage errors.

For the load voltage, the two controls reach suitably the intermediary voltage levels.

We note that the PWM method not pose any difficulty for analogical realisation. But it requires a large computation frequency in the case of digital implementation. Due to this technologic constraint, the experiment study was conducted only for the hybrid control in the next section.

\section{EXPERIMENTAL RESULTS}

The experiment study of the hybrid control was conducted with an equipment composed of a three cell converter $\left(\mathrm{C}_{1}=\mathrm{C}_{2}=33 \mu \mathrm{F}\right)$ fed by a continuous supply $(\mathrm{E}=120 \mathrm{~V})$ and associated to a passive load $(\mathrm{R}=33 \Omega$, $\mathrm{L}=50 \mathrm{mH}$ ). The proposed control algorithm is implemented in $\mathrm{C}$ language and computations are performed by a dSpace dS1104 controller board. The sampling period is fixed to $70 \mu$ s since $L / R$ is about $1.5 \mathrm{~ms}$. For each period, an interruption starts and the proposed control determines the switching states $\underline{\mathrm{U}}(\mathrm{t})=\left[\begin{array}{lll}\mathrm{u}_{1} & \mathrm{u}_{2} & \mathrm{u}_{3}\end{array}\right]^{\mathrm{T}}$ to apply. The numeric outputs of the $\mathrm{dS} 1104$ are used to control the converter drivers by optical fibres. Data recording and reference value tuning are performed within the Control Desk environment.

The voltages references are chosen as $\mathrm{E}_{1} \mathrm{c}=\frac{\mathrm{E}}{3}, \mathrm{E}_{2} \mathrm{c}=\frac{2 \mathrm{E}}{3}$ while a sinusoidal current reference is imposed.

Many tests are made for different values of the factor $\boldsymbol{\mu}$ in order to show its influence on the tracking quality.

At first, a small value of $\boldsymbol{\mu}$ is chosen to favour the current tracking as shown in Fig. 15. Voltages references are maintained with about $\pm 3 \mathrm{~V}$ oscillation amplitude (Fig. 16).

The load voltage levels are given by Fig. 17. It can be noted that four voltage levels can be obtained.

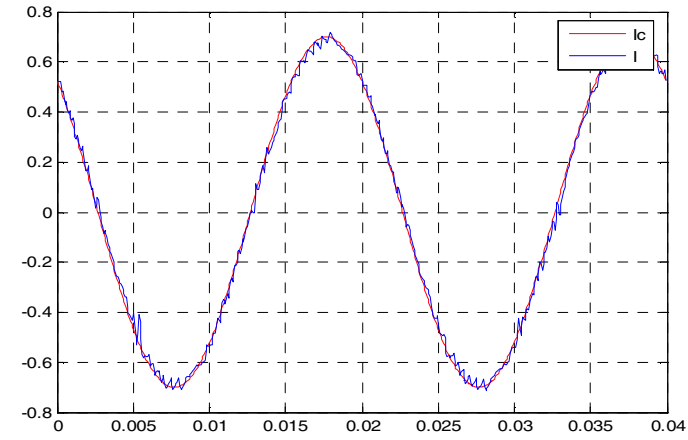

Fig. 15. Load current (A) versus time (s)
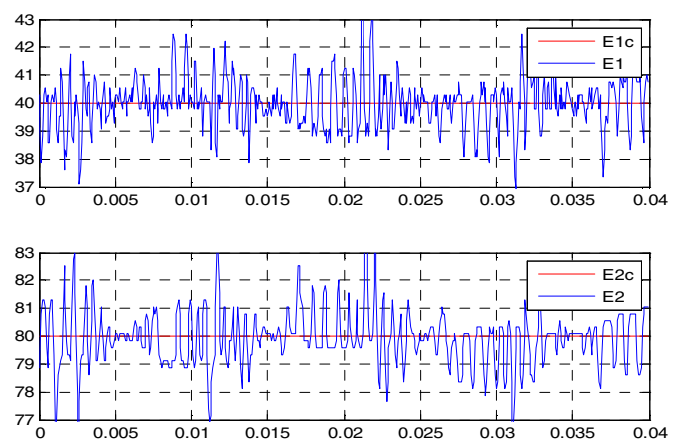

Fig. 16. Capacitor voltages (V) versus time (s)

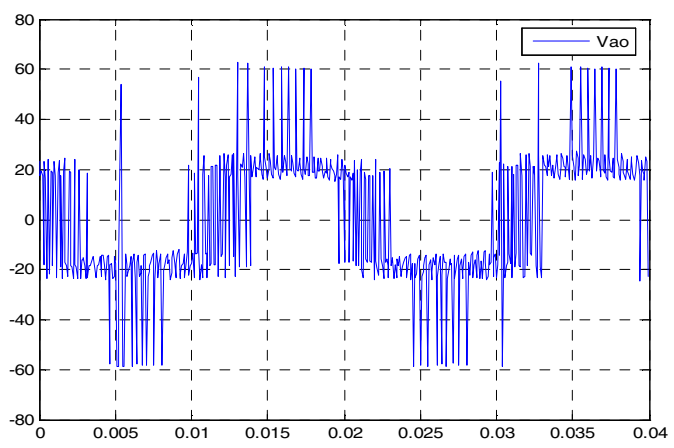

Fig. 17. Load voltage (V) versus time (s)

In the second time, the test is made with increasing the value of $\boldsymbol{\mu}$. It can be noted the deterioration of the current tracking (Fig. 18) and the improvement of the capacitor voltages which is maintained to reference values with about $\pm 1.9 \mathrm{~V}$ oscillation amplitude (Fig. 19).

Finally, a test is made while a square current reference is imposed (Fig.20). 


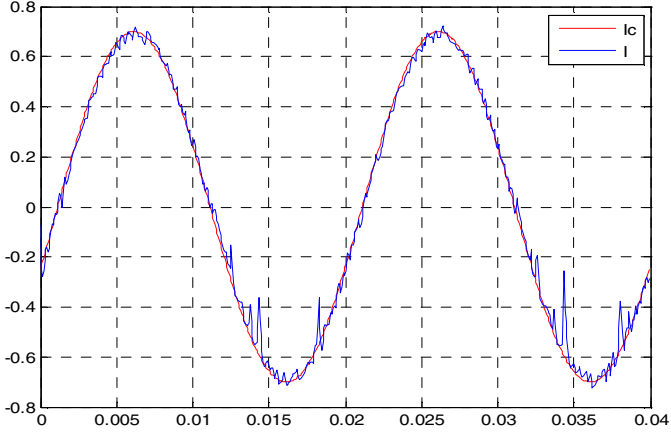

Fig. 18. Load current (A) versus time (s)
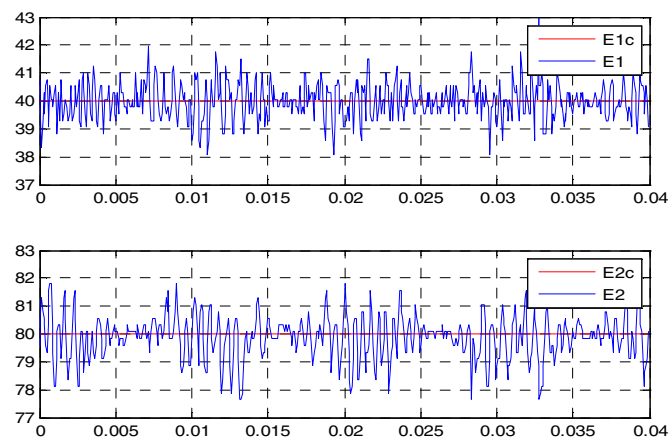

Fig. 19. Load current (A) versus time (s)

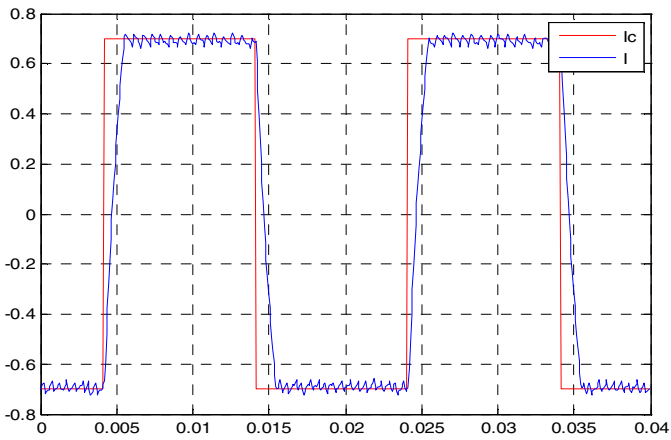

Fig. 20. Load current (A) versus time (s)

We note that the measured load current reaches the reference value after $1.5 \mathrm{~ms}$. This value refers to the $\mathrm{L} / \mathrm{R}$ ratio.

\section{CONCLUSION}

In this paper, a hybrid control strategy has been presented for the control of a three-cell DC-DC converter. It is based on a hybrid model in which both discrete and continuous variables are considered. Due to the real-time constraint, a simplified model is used. For real-time implementation, the validity of the simplified model is demonstrated. The choice of the reference voltages is justified. This paper presents a comparative simulation study between the classic PWM control and the proposed hybrid control which proves the advantages of the exposed approach. The experimental results are exposed with explaining the influence of the normalization and the weighting factor for a suitable reaching of the references.

\section{REFERENCES}

[1] L.M. Tolbert and F.Z. Peng, "Multilevel converters for large electric drives", Proc. IEEE APEC'98, vol. 2, pp. 530-536, February1998.

[2] T. A. Meynard, H. Foch, P. Thomas, J. Courault, R. Jakob and M. Nahrstaedt, "Multi-cell converters: basic concepts and industry applications", IEEE Transaction on Industrial Applications, vol. 49, no. 5, p. 955-964, October 2002.

[3] P.M. Bhagwat and V.R. Stefanovic, "Generalized structure of a multilevel PWM inverter", IEEE Trans. on Industrial Applications. vol. 32, pp 509-517, May/June 1996.

[4] G. Gateau, M. Fadel, P. Maussion, R. Bensaid and T. Meynard, "Multicell converters: active control and observation of flyingcapacitor voltages", IEEE Trans. on Industrial Electronics, vol. 49, no. 5, pp 998-1008, October 2002.

[5] H. Sira-Ramirez, R. Perez-Moreno, R. Ortega and M. GarciaEsteban, "Passivity-based controllers for the stabilization of dc-todc power converters", Automatica, vol. 33, no. 4, pp. 499-513, April 1997.

[6] B. Potoenik, G. Music and B. Wupancic, "Model predictive control of discrete-time hybrid systems with discrete inputs", ISA Transactions, vol. 44, no. 2, April 2005.

[7] M. Baja, D. Patino, H. Cormerais, P. Riedinger and J. Buisson, "Hybrid control of a three-level three-cell dc-dc converter", American control conference, p. 5458 - 5463, July 2007. 